\title{
Practical Learning Based on Virtual Reality Methods as a Solution to Increase Evaluation Level 1 Results in Practical learning at PT PLN (Persero) UPDL Palembang
}

\author{
Fajrie Agus Dwino Putra ${ }^{1, *}$ Supli Efendi Rahim ${ }^{2}$ Zulhipni Reno Saputra. ${ }^{3}$ \\ ${ }^{1}$ Instructor, PT PLN (Persero) UPDL Palembang, Palembang, Indonesia \\ ${ }^{2}$ Lecturer, Kader Bangsa University, Palembang, Indonesia \\ ${ }^{3}$ Lecturer, Muhammadiyah University, Palembang, Indonesia \\ *Corresponding author. Email: fadp82@gmail.com
}

\begin{abstract}
During the Covid 19 pandemic, all learning cannot be carried out face-to-face, especially with learning that requires a practicum. Based on these problems, the authors researched the form of research and development based on quantitative research methods. Practical learning based on the virtual reality learning method is an online practicum learning solution. The Virtual practical learning method is a learning method that can increase the evaluation level 1 (material quality, instructor quality, and practice media quality) at PT PLN (Persero) UPDL Palembang. The implementation of this method uses the latest audio-visual technology by utilizing virtual reality technology with a 3600 - video format that is more attractive and interactive so that it can motivate learning participants when carrying out online practical learning. After the practical learning material is made in Virtual reality video format, the learning participants can use the video to be played by smartphone and virtual reality glasses. By watching virtual practice learning videos, learning participants will feel that they are in real conditions in practice learning. The Virtual practical learning method can be used for practical learning materials, both technical and non-technical, and adapted to the appropriate supporting video according to the learning material. The Virtual practical learning can be used by participants at any time when they are in their respective units or can be shared according to permission from PT PLN (Persero) PUSDIKLAT.
\end{abstract}

Keywords: Virtual reality, Practical learning, 360-degree video, a satisfaction of practical learning participants.

\section{INTRODUCTION}

Since the Covid 19 outbreak in 2020, all face-to-face learning has been cancelled, and then all learning is done online. PT PLN (Persero) UPDL Palembang as a unit of PLN PUSDIKLAT which is responsible for providing education and training to all PLN'S employers in its regional units to improve the competence of employees of PLN Regional units. The PLN units that are regional by PT PLN (Persero) UPDL Palembang are: PT PLN (Persero) UIW Sumatra Selatan Jambi and Bengkulu Region, PT PLN (Persero) UIW Bangka Belitung, PT PLN (Persero) UID Lampung, PT PLN (Persero) UIK Sumatera Selatan, and PT PLN (Persero)
UIP Sumatera Selatan. The total number of employees is 4000 employees.

Based on the data we have currently, from 43 titles of practical learning, only 5 titles of learning can only be implemented in 2021 . The seven titles of practical learning are held with improvised methods and carried out online. After the practical learning held PLN UPDL ask a questioner evaluation level 1 from the participant. The results of the evaluation level 1 of online practice learning are not good; this can be seen in table 1. 
Table 1. Evaluation Level 1 Results Practice online learning with a blended learning method

\begin{tabular}{|c|c|l|c|}
\hline No & Date & \multicolumn{1}{|c|}{ Learning Title } & $\begin{array}{c}\text { Evaluat } \\
\text { ion } \\
\text { Result }\end{array}$ \\
\hline 1 & 07 June 2021 & $\begin{array}{l}\text { K2 and K3 at HV/ EHV } \\
\text { installation for job executors }\end{array}$ & 3,19 \\
\hline 2 & 07 June 2021 & $\begin{array}{l}\text { Distribution network operating } \\
\text { pattern system 1.5 breaker }\end{array}$ & 3,46 \\
\hline 3 & 07 June 2021 & $\begin{array}{l}\text { Distribution operating system } \\
\text { settings }\end{array}$ & 3,33 \\
\hline 4 & 14 June 2021 & $\begin{array}{l}\text { Distribution operating system } \\
\text { settings }\end{array}$ & 3,5 \\
\hline 5 & 21 June 2021 & $\begin{array}{l}\text { Distribution network operating } \\
\text { pattern system 1.5 breaker }\end{array}$ & 3.20 \\
\hline
\end{tabular}

The other 36 practical learning titles are still being postponed while waiting for face-to-face learning to be allowed by the government. The schedule plan for implementing practical learning at PT PLN (Persero) UPDL Palembang can be seen in table 2 .

Table 2. The schedule plan for implementing practical learning at PT PLN (Persero) UPDL Palembang

\begin{tabular}{|c|c|c|}
\hline No & Date & Learning Title \\
\hline 1 & 05 July 2021 & Indirect Meter wiring \& testing \\
\hline 2 & 26 July 2021 & Testing distribution CT/PT \\
\hline 3 & 26 July 2021 & $\begin{array}{l}\text { Distribution network operation with } \\
\text { SCADA }\end{array}$ \\
\hline 4 & 23 August 2021 & $20 \mathrm{kV}$ cubicle Installation \\
\hline 5 & 23 August 2021 & $\begin{array}{l}\text { Analysis and evaluation of the impact of } \\
\text { harmonics on distribution transformers }\end{array}$ \\
\hline 6 & 23 August 2021 & $\begin{array}{l}\text { Distribution network construction } \\
\text { supervisor }\end{array}$ \\
\hline 7 & 23 August 2021 & $\begin{array}{l}\text { Wiring and testing LV/MV meter direct } \\
\text { and indirect measurement }\end{array}$ \\
\hline 8 & 23 August 2021 & $\begin{array}{l}\text { Preparation and evaluation of } \\
\text { environmental documents }\end{array}$ \\
\hline 9 & 23 August 2021 & $20 \mathrm{kV}$ cubicle operation \\
\hline 10 & 23 August 2021 & DCS Power Plan \\
\hline 11 & 23 August 2021 & $\begin{array}{l}\text { Distribution system maintenance } \\
\text { planning }\end{array}$ \\
\hline 12 & 30 August 2021 & $\begin{array}{l}\text { Analysis and evaluation of the } \\
\text { management of customer complaints and } \\
\text { complaints using APKT in the } \\
\text { distribution sector }\end{array}$ \\
\hline 13 & 30 August 2021 & Testing distribution CT/PT \\
\hline 14 & 30 August 2021 & $\begin{array}{l}\text { Distribution system maintenance } \\
\text { planning }\end{array}$ \\
\hline 15 & 06 Sep 2021 & Setting and Checking 1 phase meter \\
\hline 16 & 06 Sep 2021 & $\begin{array}{l}\text { Distribution system development } \\
\text { planning }\end{array}$ \\
\hline 17 & 06 Sep 2021 & $\begin{array}{l}\text { Distribution network operation with } \\
\text { SCADA }\end{array}$ \\
\hline 18 & 06 Sep 2021 & $\begin{array}{l}\text { Analysis and evaluation of the impact of } \\
\text { harmonics on distribution transformers }\end{array}$ \\
\hline 19 & 13 Sep 2021 & Wiring and testing LV meter \\
\hline 20 & 13 Sep 2021 & Wiring and testing MV meter \\
\hline
\end{tabular}

Source: Learning Management System PT PLN (Persero) Pusdiklat

Based on this background, the problems to be studied can be formulated.

\section{LITERATURE REVIEW AND HYPOTHESES}

\subsection{Kirkpatrick; Level 1 Evaluation Learning Results}

Level 1 evaluation is an evaluation to determine the reactions of learning participants. The implementation of level 1 evaluation is carried out by giving questionnaires to learning participants to find out the reactions of learning participants to the training provided. That way we can find out whether customers are satisfied or not with the implementation of learning [1].

The questions on the questionnaire to find out the reactions of the learning participants can be in the form of questions about they feel about the instructor's quality, the topics are given, materials, presentations, and training facilities.

Reactions are measured to be a reference in the future so that the training program becomes more effective and constantly evolving, as well as detecting whether there is material left behind and not delivered.

The level one evaluation is done to check the quality of the instructor, the quality of the learning materials, and the learning media.

\subsection{Instructor Quality}

A good instructor can provide changes in knowledge, attitudes, behaviour, skills, and skills, by interacting with participants during training. In the training process, participants get new knowledge, new views, new behaviours, new ways of working, new skills, and new skills.

Instructor competency standards are used as guidelines for assessing the ability of instructors in the implementation of learning. The competency standards for instructors must meet the following:

a. Standards of pedagogic competence, skill competence, and social competence are generally applicable to all instructors.

b. Professional standards according to the area of expertise or skills being taught.

Table 3 shows of Instructor competencies include the formulation of competencies and sub-competencies as implementers of learning in training which is described in pedagogic competencies, personality competencies, social competencies, and professional competencies [7]. 
Table 3. Instructor Competency Standards

\begin{tabular}{|c|c|}
\hline Competency & Indicators \\
\hline $\begin{array}{l}\text { Pedagogic } \\
\text { Competencies }\end{array}$ & $\begin{array}{l}\text { a. Understand the characteristics of the } \\
\text { trainees, } \\
\text { b. Mastering learning theory and training } \\
\text { learning principles, } \\
\text { c. Mastering the concepts, principles, and } \\
\text { procedures of development, } \\
\text { d. Mastering theories, principles, and } \\
\text { learning strategies. }\end{array}$ \\
\hline $\begin{array}{l}\text { Professional } \\
\text { Competencies }\end{array}$ & $\begin{array}{l}\text { a. Mastery of the field of expertise which is } \\
\text { the main task, } \\
\text { b. Ability to explain the relationship with the } \\
\text { field of expertise, } \\
\text { c. Develop training materials for the } \\
\text { respective areas of expertise or skills } \\
\text { being trained. }\end{array}$ \\
\hline $\begin{array}{l}\text { Personality } \\
\text { Competencies }\end{array}$ & $\begin{array}{l}\text { a. Have good behavior and role models for } \\
\text { trainees and the community, } \\
\text { b. Presenting oneself as an honest, friendly, } \\
\text { social, humane person, noble character, } \\
\text { tolerant, stable, wise, and authoritative as } \\
\text { an instructor, } \\
\text { c. Have a democratic spirit, attitude, and } \\
\text { behavior. }\end{array}$ \\
\hline $\begin{array}{l}\text { Social } \\
\text { Competencies }\end{array}$ & $\begin{array}{l}\text { a. Ability to express opinions } \\
\text { b. Ability to accept criticism, suggestions, } \\
\text { and opinions of others. }\end{array}$ \\
\hline
\end{tabular}

Source: Regulation of the Minister of Education and Culture of the Republic of Indonesia No. 90 year 2014

\subsection{Practical Learning Media}

By using learning media that are more concrete or with direct experience, the message (information) in the learning process delivered by the instructor to the learning participants will be delivered properly. On the other hand, if the learning media is abstract, then the message (information) will be difficult for the learning participants to accept, in other words, they will difficulties in understanding and digesting what is told by the instructor. The acquisition of knowledge and skills, changes in attitudes and behaviour can occur because of the interaction between new experiences and experiences that have been experienced previously [2]. Therefore, the use of appropriate learning media will have a direct impact on the acquisition and growth of the knowledge, skills, and attitudes of the trainees. Various learning media can be classified based on certain characteristics. Rudy Brets made a Classification based on the three characteristics [8]:
a. Audio
b. Visual
c. Motion

\subsection{Virtual Reality}

Virtual reality is a technology that can create an artificial environment with the help of software. The results of the artificial environment will be displayed to users with the intention that they can feel, hear, and see directly but through virtual reality technology.

Video in virtual reality format is an image in 3D that can be displayed through special media so that users will feel where the image is displayed.

In its application, virtual reality technology is divided into:

a. Simulation of a real environment for educational and training purposes,

b. Development of an artificial environment for playing games.

An illustration of how to use and the function virtual reality technology can be seen in Figure 1.

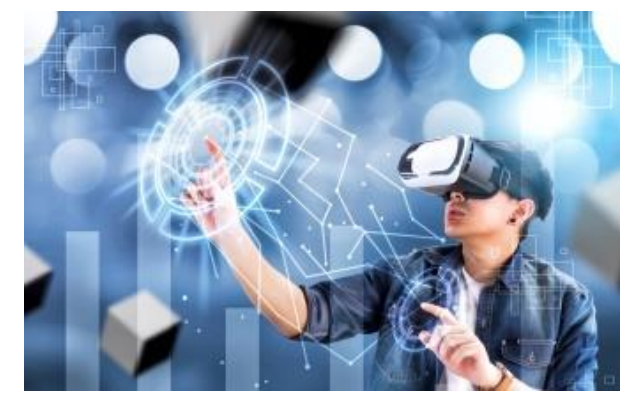

Source: https://sluntu.com/jenis-dan-cara-kerja-virtual-reality/

Figure 1 Virtual reality illustration.

\subsection{Hypotheses}

The hypothesis in this paper is H1: Can the virtual reality practice method improve the results of the level 1 evaluation survey for practical learning.

\section{METHODS}

\subsection{Research Methods}

The research method used in this research is Research and Development (R\&D). Research and Development $(R \& D)$ is a research method that is quite powerful to improve practice [3].

A new online practical learning method will be developed by utilizing virtual reality technology.

Research and development are carried out by making learning methods in which there is the delivery of learning materials through virtual reality videos. Learning videos are made by developing practical learning materials and practicum instructions, and then the materials and practicum instructions are made into practical learning videos in virtual reality format.

It is hoped that this virtual reality learning method will improve the results of level one evaluation related to the quality of the material, the quality of the 
instructors, and the quality of the practical learning media at PT PLN (Persero) UPDL Palembang.

\subsection{Development Procedure}

The research and development of this virtual reality practice learning method will be carried out based on a procedural model approach, namely a descriptive model and outlines the development steps. The steps that must be followed to produce a product include the potential and problem stages, data collection, product design, design validation, product design revision, product testing, product revision, usage trial, revision products, and mass production [4]. The development research procedures to be carried out can be seen in Figure 2 .

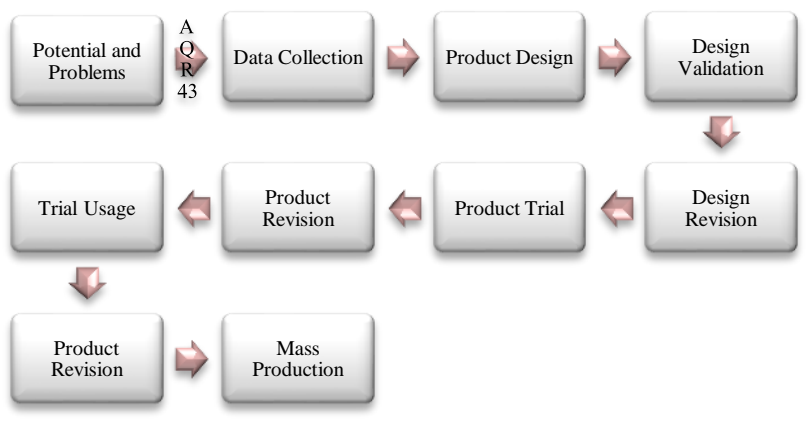

Figure 2 Development Research Procedures.

\subsection{Data Analysis}

To ensure practical learning with virtual reality media is following the learning needs in the curriculum and syllabus, a trial of research and development results is carried out. The first test is the assessment stage which is carried out by 1 expert on practical learning materials and 1 expert in making virtual reality learning videos. Then the practicum learning materials made in the virtual reality video format were revised according to the direction of the experts, and then a trial was conducted on the use of these learning materials in virtual reality-based online practical learning by teachers and learning participants. Testing the use of virtual reality-based online practicum learning methods was carried out twice, namely in limited trials and use trials. Subjects in the limited trial were 1 instructor and 6 participants in practical learning. Based on the results of a limited trial, the product was revised. The results of the product revision in the limited trial will then be used in the use trial. The material in the trial use is in one of the practicum lessons that have been scheduled and must be following the learning materials that have been made in the virtual reality learning video.

Based on the results of the trial use, the product was revised to produce a final product. Then it can be produced or developed in other practicum learning titles.

\section{RESULTS}

\subsection{Product Design}

The first step is making practical learning materials in virtual reality video format. Video materials are made based on practical learning materials and practical instructions that are already available in face-to-face learning materials. Materials and practical instructions were then translated into the form of scenarios and scripts. Creating of scripts and scenarios is carried out by an expert in virtual reality videos and help by someone who is an expert in practical learning materials. The flow of the process of making practical learning materials videos based on virtual reality can be seen in Figure 3.

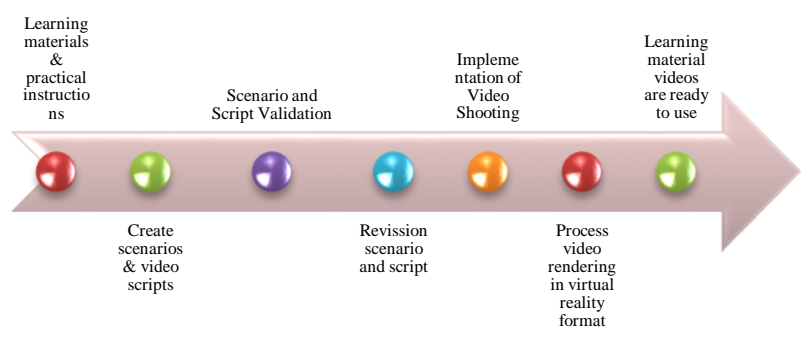

Source: Business Process Model Virtual Reality PLN PUSDIKLAT

Figure 3 The flow of the process of making practical learning materials videos based on virtual reality

Documentation of activities when making practical learning materials videos based on virtual reality can be seen in figure 4.
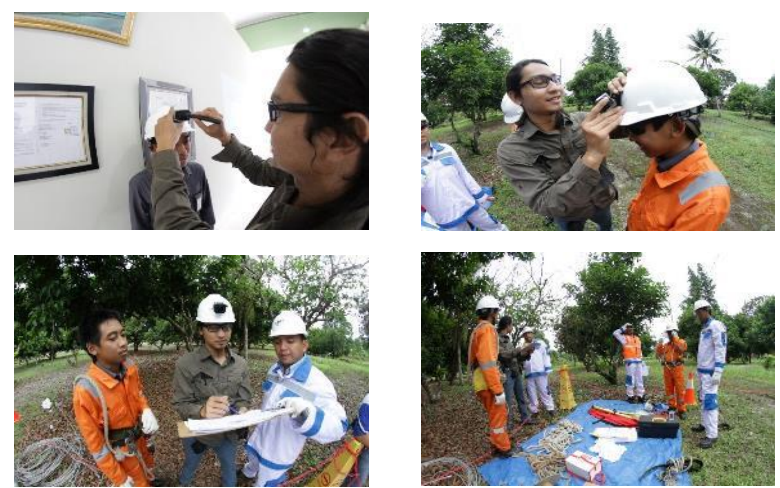

Source: Personal Documentations

Figure 4 The activity of making practical learning materials videos

The next stage, after the video material is ready, is then made a standard operating procedure for practical learning methods based on virtual reality. The practical learning methods based on virtual reality rules can be seen in table 4. 
Table 4. Standard operating procedures for practical learning method based on virtual reality

\begin{tabular}{|c|c|c|c|c|c|}
\hline No & Description of activities & $\begin{array}{l}\text { PLN UPDL } \\
\text { Palembang }\end{array}$ & Instructors & Participants & $\begin{array}{c}\text { Participant } \\
\text { leaders }\end{array}$ \\
\hline 1 & Online delivery of theoretical learning materials by instructors & & & & \\
\hline 2 & Explanation of online practicum learning by the instructor & & & & \\
\hline 3 & $\begin{array}{l}\text { Sending assignment letters for practical learning on the On } \\
\text { Job Training scheme and video practicum based on virtual } \\
\text { reality by PLN UPDL Palembang }\end{array}$ & & & & \\
\hline 4 & $\begin{array}{l}\text { Participants get a practicum assignment letter and a virtual } \\
\text { reality practicum learning video }\end{array}$ & & & & \\
\hline 5 & $\begin{array}{l}\text { Learning participants coordinate with their leaders for } \\
\text { practical implementation in the sited }\end{array}$ & & & & \\
\hline 6 & $\begin{array}{l}\text { Participants watch practical learning videos using virtual } \\
\text { reality glasses }\end{array}$ & & & & \\
\hline 7 & $\begin{array}{l}\text { Learning participants carry out direct practice in the sited } \\
\text { with the assistance of their leaders }\end{array}$ & & & & \\
\hline & $\begin{array}{l}\text { The leader of the learning participants gives an assessment to } \\
\text { the participants on the implementation practicum learning } \\
\text { based virtual reality }\end{array}$ & & & & \\
\hline 9 & $\begin{array}{l}\text { Participants send feedback on practicum learning together } \\
\text { with an assessment form for participant practicum results by } \\
\text { their leaders to PLN UPDL Palembang }\end{array}$ & & & & \\
\hline 10 & $\begin{array}{l}\text { PLN UPDL Palembang sent assessment form for participant } \\
\text { practicum results to instructors }\end{array}$ & & & & \\
\hline 11 & $\begin{array}{l}\text { The instructor sends back a summary of the list of scores of } \\
\text { all participants to PLN UPDL Palembang }\end{array}$ & & & & \\
\hline 12 & 2 PLN UPDL Palembang issues training certificate & & & & \\
\hline
\end{tabular}

Source: PT PLN (Persero) UPDL Palembang

\subsection{Product Testing and Trial}

The trial and testing of the practical learning method based on virtual reality were carried out on one of the learning titles whose video material had been made. The trial and testing were carried out in 2 stages. The first stage is internal testing. This trial was carried out by 1 instructor and 6 employees of PLN UPDL Palembang as learning participants. This first trial was carried out in practical learning with the title "Indirect Meter wiring \& testing". During the practice learning based on the virtual reality process, the instructor is always involved. Participants were instructed by the instructor to watch videos of practical learning materials with virtual reality equipment, and then the participants were asked to demonstrate according to the video practicum materials they watched. The instructor observes all activities when the participants practice directly and provides an assessment during the practicum. Figure 5 shows the condition of practicum learning participants watching videos of practical learning materials with the help of virtual reality glasses.

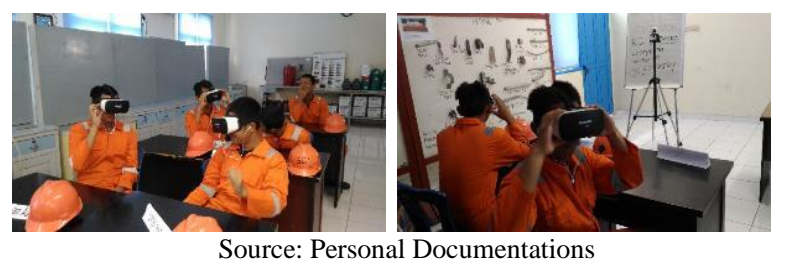

Figure 5 Participants watching a video of practical learning materials
Based on the instructor's observations in the first phase of the trial, it can be concluded that the practical learning method based on virtual reality is very effective and can be implemented for all online practicum learning. All participants were declared capable of doing practical activities according to the material on the virtual reality videos they watched. By watching videos of practical learning materials based on virtual reality, participants can feel their presence directly in the video. Using virtual reality, participants can see the condition of the practice situation in 360 degrees.

The second stage is an external trial, conducted on participants from the PLN operational Unit. In this second trial, it was carried out in practicum learning with the title "Indirect Meter wiring \& testing" which was scheduled. The practical learning was carried out from July 5, 2021, until July 12, 2021, with 14 participants from PLN UIW Babel, PLN UIW S2JB, and PLN UID Lampung. The implementation of the trial followed the SOP set out in table 4.

Based on observations during the testing process, it can be concluded that practical learning methods based on virtual reality are very effective to solved problems in online practical learning. All participants who take part in the study are declared to have passed and are entitled to receive a training certificate. The results of the evaluation level 1 that was filled in by participants got the highest score compared to the learning before the implementation of practical learning methods based on virtual reality.

\subsection{Evaluation Level 1 Result}

After a trial was carried out on one of the practice learning at PLN UPDL Palembang and it was declared that the learning was effective, so another practice learning video was made whose the practice learning were scheduled for this year. Due to the limited time of the study, the researchers only observed the results of the evaluation of level 1 in practice learning until September 2021. Table 5 showing the results of the evaluation level 1 of practice learning up to September 2021

Table 5 Evaluation Level 1 Results of Practical Learning Based on Virtual Reality Methods

\begin{tabular}{|l|l|l|l|}
\hline No & Date & Learning Title & $\begin{array}{l}\text { Evalua } \\
\text { tion } \\
\text { Result }\end{array}$ \\
\hline 1 & 05 July 2021 & $\begin{array}{l}\text { Indirect Meter wiring \& } \\
\text { testing }\end{array}$ & 3.84 \\
\hline 2 & 26 July 2021 & Testing distribution CT/PT & 3.61 \\
\hline 3 & 26 July 2021 & $\begin{array}{l}\text { Distribution network } \\
\text { operation with SCADA }\end{array}$ & 3.87 \\
\hline 4 & 23 August 2021 & 20 kV cubicle Installation & 3.91 \\
\hline 5 & 23 August 2021 & $\begin{array}{l}\text { Analysis and evaluation of } \\
\text { the impact of harmonics on } \\
\text { distribution transformers }\end{array}$ & 3.61 \\
\hline 6 & 23 August 2021 & $\begin{array}{l}\text { Distribution network } \\
\text { construction supervisor }\end{array}$ & 3.54 \\
\hline
\end{tabular}




\begin{tabular}{|l|l|l|l|}
\hline 7 & 23 August 2021 & $\begin{array}{l}\text { Wiring and testing LV/MV } \\
\text { meter direct and indirect } \\
\text { measurement }\end{array}$ & 3.83 \\
\hline 8 & 23 August 2021 & $\begin{array}{l}\text { Preparation and evaluation of } \\
\text { environmental documents }\end{array}$ & 3.76 \\
\hline 9 & 23 August 2021 & 20 kV cubicle operation & 3.76 \\
\hline 10 & 23 August 2021 & DCS Power Plan & 3.61 \\
\hline 11 & 23 August 2021 & $\begin{array}{l}\text { Distribution system } \\
\text { maintenance planning }\end{array}$ & 3.73 \\
\hline 12 & 30 August 2021 & $\begin{array}{l}\text { Analysis and evaluation of } \\
\text { the management of customer } \\
\text { complaints using APKT in } \\
\text { the distribution sector }\end{array}$ & 3.82 \\
\hline 13 & 30 August 2021 & Testing distribution CT/PT & 3.73 \\
\hline 14 & 30 August 2021 & $\begin{array}{l}\text { Distribution system } \\
\text { maintenance planning }\end{array}$ & 3.63 \\
\hline 15 & 06 Sep 2021 & $\begin{array}{l}\text { Setting and Checking 1 phase } \\
\text { meter }\end{array}$ & 3.62 \\
\hline 16 & 06 Sep 2021 & $\begin{array}{l}\text { Distribution system } \\
\text { development planning }\end{array}$ & 3.53 \\
\hline 17 & 06 Sep 2021 & $\begin{array}{l}\text { Distribution network } \\
\text { operation with SCADA }\end{array}$ & 3.70 \\
\hline 18 & 06 Sep 2021 & $\begin{array}{l}\text { Analysis and evaluation of } \\
\text { the impact of harmonics on } \\
\text { distribution transformers }\end{array}$ & 3.92 \\
\hline 19 & 13 Sep 2021 & Wiring and testing LV meter & 4.00 \\
\hline 20 & 13 Sep 2021 & Wiring and testing MV meter & 4.87 \\
\hline
\end{tabular}

Source: Learning Management System PT PLN (Persero) PUSDIKLAT

Based on the results of the evaluation level 1, it can be concluded that the practical learning method based on virtual reality can improve the results of the evaluation level 1 of practical learning at PLN UPL Palembang.

\section{DISCUSSION}

The results of the study show that the practice learning method based on virtual reality can improve the evaluation level 1 results. The practice learning method based on virtual reality can increase the motivation of learning participants because participants can feel experience practical activities before carrying out the actual practice. Virtual reality becomes an intermediary media that makes it easier for instructors to deliver material so that learning becomes effective and efficient. Even after learning, participants can still playback videos practice material bases on virtual reality whenever and wherever they are as a refreshment of knowledge.

Due to the limited time of the study, the authors only discuss up the improvement of evaluation level 1 results. According to Kirkpatrick, there are 4 levels of learning evaluation, to determine the effectiveness of learning can be seen from the results of the evaluation of level 1 to level 4 (Kirkpatrick et al., 2006). For further researchers may be able to research the effectiveness of online practice learning by looking at the results of the evaluation of levels 1 to level 4 . In addition, further researchers can develop practicum learning methods based on virtual reality by creating virtual games for practical learning.

\section{AUTHORS' CONTRIBUTIONS}

Fajrie Agus D.P. has a problem to analyze. Zulhipni Reno S. provides problem solving ideas. Supli Efendi Rahim provides input related to research methods. Zulhipni Reno S. and Supli Efendi R. developed the theory and performed the computations. Supli Efendi R encouraged Fajrie Agus D.P. to investigate (a specific aspect) and supervised the findings of this work. All authors discussed the results and contributed to the final manuscript.

\section{ACKNOWLEDGMENTS}

Thanks' to managements of PT PLN (Persero) UPDL Palembang already support for all information and data. Thanks' to all laboratories team in PT PLN (Persero) UPDL Palembang already help at virtual reality video shooting.

\section{REFERENCES}

[1] Syafrill, Ramadhon, Penerapan Model Empat Level Kirkpatrick dalam Evaluasi Program Pendidikan Dan Pelatihan Aparatur di Pusdiklat Migas. Jurnal Swara Patra Vol. 6 No. 1, 2016, pp. 45-46.

[2] Arsyad, Azhar, Media Pembelajaran. PT. Raja Grafindo Persada, 2011.

[3] Sukmadinata, Nana Syaodih, Metode Penelitian Pendidikan, PT.Remaja Rosdakarya, vol 2, 2006.

[4] Sugiyono. Metode Penelitian Kuantitatif Kualitatif dan R\&B. Alfabeta. 2012, pp. 409.

[5] Kirkpatrick, Donald L. Kirkpatrick, James D. Evaluating Training Programs: The Four Levels. Berrett-Koehler. Third edition, 2006.

[6] Sharon E. Smaldino, Deborah L. Lowther, Clif Mims, Instructional Technology and Media for Learning, Pearson, 12th Edition, 2019.

[7] Menteri Pendidikan dan kebudayaan, Standar kualifikasi dan kompetensi instruktur pada kursus dan pelatihan, Permen No. 90, 2014.

[8] Rudy Bretz,. Teknologi Komunikasi Pendidikan, Jakarta: Rineka Cipta, 1971.

[9] Kadek Y.D, N. sugihartini, I.K. Resika A, Pengaruh Penggunaan media Virtual Reality dengan Model Pembelajaran Klasikal Terhadap Hasil Belajar Siswa di TK negeri pembina singaraja, Jurnal Pendidikan Teknologi \& Kejuruan Vol. 15, No. 2, Juli 2018, Hal :298.

[10] Yulia I, Fungsional Pengembang Teknologi Pembelajaran (PTP) LPMP Bengkulu, website: https://lpmpbengkulu.kemdikbud.go.id/, download 05 June 2021. 